\title{
فاعلية تطوير الإعداد التربوي للطالب المعلم بكلية التربية النوعية وتأثيره على أدائه في التدريب الميداني ل
}

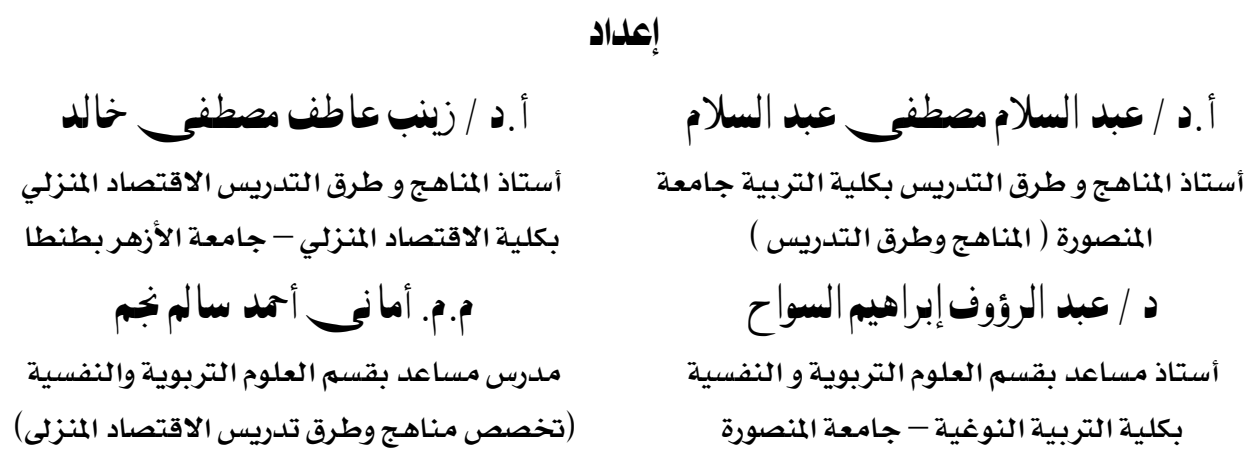

مجلة بحوث التزبية النوعية ـ جامعة المنصورة

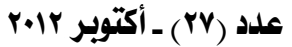




\section{فاعلية تطوير الإعداد التربوي للطالب المعلم بكلية التربية النوعية وتأثيره على أدائه في التدريب الإيداني}

إعداد

$* *$

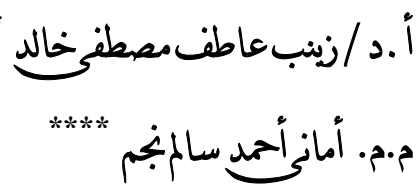

* أ .د / عبد السلام مصطغ عبد السلام

$* * *$ د /عبد الرؤوف إبراهيمالسواح

يعرض هذا الفصل ملخصا للبحث والنتائج التى توصل ليها ثم التوصيات وفيما يلى عرضـا لكل جانب من هذه الجوانب : .

أولا : هلخص البهث من هده

تخـتص كليـات التربيسة عمومها وكليـات التربيسة النوعيـة بإعـداد طلابهـا تربويـا وتنميسة

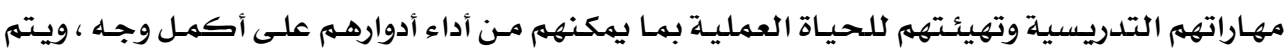

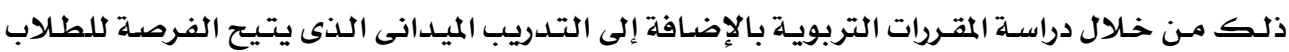

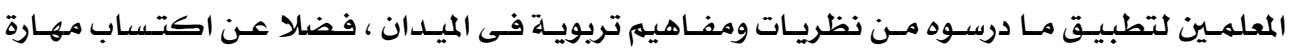
إدارة الصف .

ولما كانت غالبية التخصصات الموجودة فى كليات التربية النوعية تمثل مواد المجالات فإنها

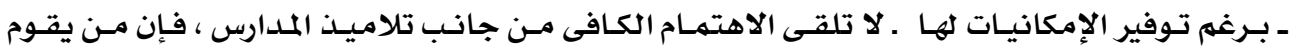

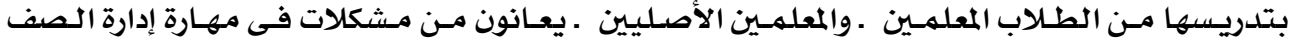

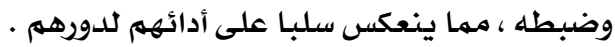

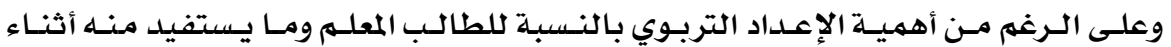

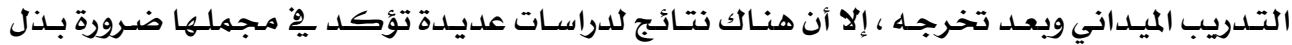

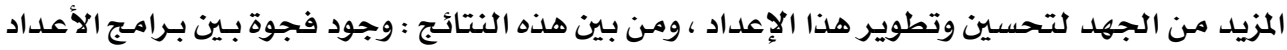

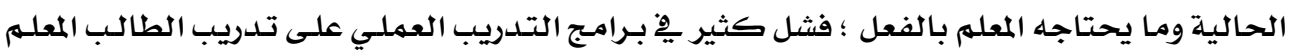

* أستاذ المناهج و طرق التدريس بكلية التربية جامعة المنصورة ( المناهج وطرق التدريس )

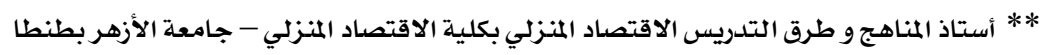

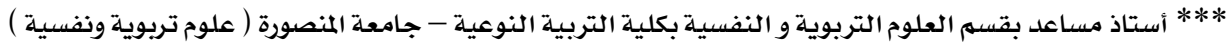
***** مدرس مساعد بقسم العلوم التربوية والنفسية (تخصص مناهج وطرق تدريس الاقتصاد المنزلي) 


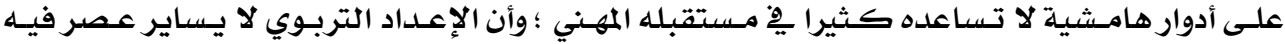
التغير السريـع أبرز السهمات .

وقد أثبتت بعض الدراسـات التربويـة وجـود فجـوة بـين بـرامـج الإعداد الحـاليـة بكليـات التربيـة

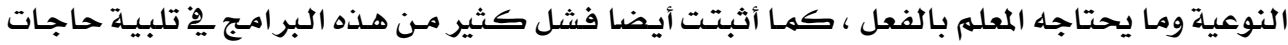
المتعلمـين فى أثناء الخدمـة واقتصار بعض برامـج التدريب الميداني على تدريب الطالب المعلم على أدوار هامشيـة لا تسـاعده كثيرا فى مستقبله الوظيفي ·

لذا فقد سعت الدراسـة الحاليـة مـن خـلال التحليـل الفعلـي للهقررات التربويـة التي يدرسهـا طالب كليـة التربية النوعية خلال سنوات الدراسـة الأربع إلى تأكيد أهميـة أن يتهم تدريس منهج يهتم بتدعيهم قدرات الطالب المعلم ويزيد من مهاراته التدريسيـة الـتي تهكنـه مـن أداء دوره بفاعليـة وبيمكن أن

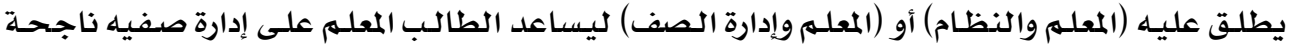
وأداء أدواره أداء جيدا .

ثازيا : وشكالة البحث :

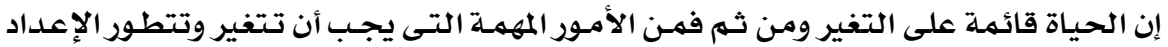
التربوى للطالب المعلهم قبل الخدمـة وإعداده الإعداد الملائم والمتنـاسـب مـع دائرة التتغير التى سـيواجهها عنـدما يتحمـل مـــاعب التـدريس وليـستطيـع تلبيـة مـتطلبـات هـذا التتغير يكـون عليـهـ أولا أن يـتغير

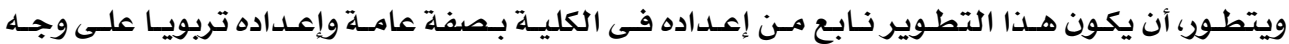

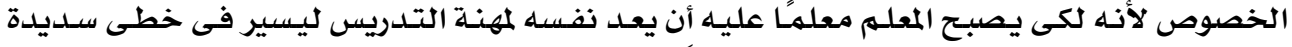

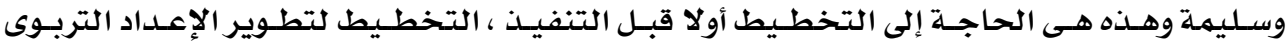

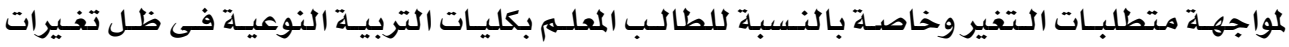
وتحسديات العـصر التـى تسـتلزم مـن المسؤلين عـن تطـوير المنـاهـج والحـرص على وضـع بعض المنــاهـج الجديلدة أو تطوير القديم من أجل تطوير إعداد الطالب المعلهم.

$$
\text { • سرعة التغير فى العصر الحديث . }
$$

• كثرة المشتتات التى تجذب المتعلم نحوها مثل الفيـيـو والبـث الفضـائى والإذاعى والتلفيزيـونى

$$
\text { والمباريات الرياضيـة وغيرها . }
$$

• المشكلات التـى أخـذت تطفـو على سـطح الحيـاة فى المجتهمعـات مثل المخدرات والتلـوث البيئىى

والإرهاب وتعرض المتعلهم بالتالى إلى أخطارها .

• تزايد حملات الغزو الثقافى بواسطة الأقمار الصناعية .

$$
\text { • التطور الذى طرأ على دور التربية . }
$$

والملاحظ أن معظم التحسديات السـابقة يعـود إلى طبيعـة التتغير السـريع الـذى يخص حياتنـا المعاصـرة وقـل آن الأوان لأن يسستثمـر المربـون معطيـات التقنيـة الحلديثـة في اسـتنبـاط أسـاليب تريويـة جديلدة وطرائق للتعلـيهم جديدة وتنظيهم للهـنـاهـج جديد واسـتخدام حـوافز جديدة وصولا إلى إصـلاح 
$\underline{\underline{ }}$

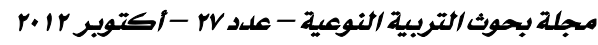

السلوك فى وقت أقل وبكفايـة أكثر • وهــا مـن أكبر التحـديات التى تواجـه التربـويـين - عمومًا -

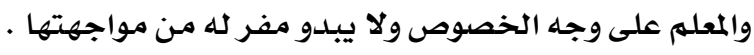

وقد أكست بعض الدراسات وجود قصور فى الإعداد التربوى وهو مـا لاحظته الباحثة أيضا

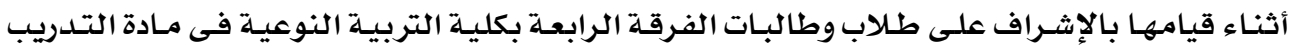

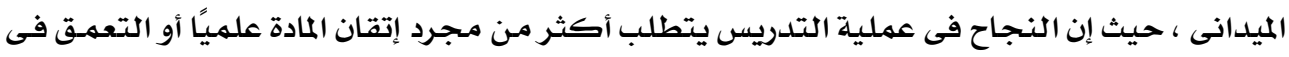

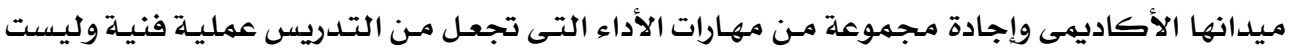
مجرد تلقين للمعلومات.

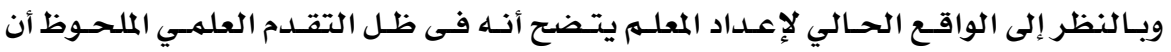

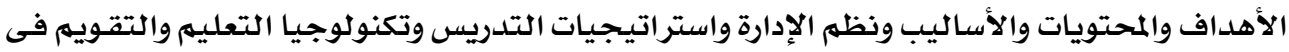

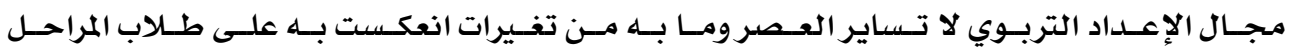

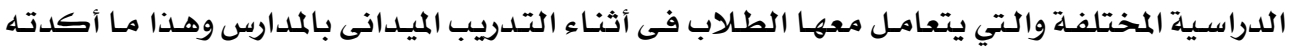

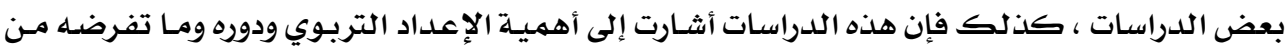

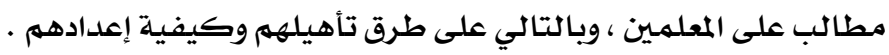
ويمكن إجمال مشكلة هذه الدراسة فى التساؤل الرئيسي التالي :كيف يمكن التخطيط لتطوير الإعـداد التربـوي لطلاب كليـة التربيـة النوعيـة ومـا تأثير ذلك على أدائهم فى التدريب الميدانى ؟

ويمكن أن يتفرع من هذا التساؤل عدة تساؤلات فرعية على النحو التالى : ا ـ ما مدى كفاية برامـج الإعداد التربوى الحالية بكليات التربية النوعية لإكساب الطالب المعلمى

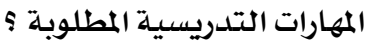

r . كيف يمكن وضع تصور مقترح لطلاب كليـة التربيـة النوعيـة فى مجال إدارة الصف والمهارات

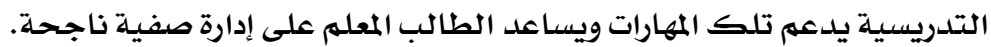

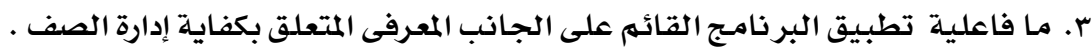

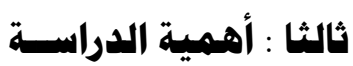
تنبـع أهمية هذه الدراسة من أنها يمكن أن تكشف عن :

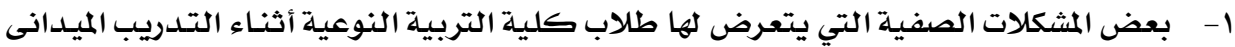

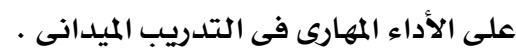

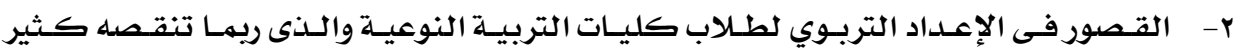

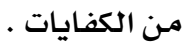

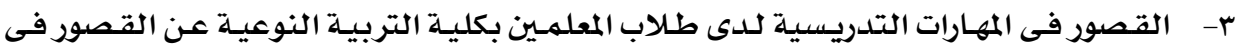

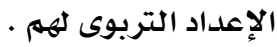
ع- أهميه تطوير الإعداد التربوي لطالب كليه التربية النوعية وفقا لمدخل الكفايات . 
تم تطبيق الدراسـة الميدانية على طلاب وطالبات الفرقة الرابعة بكلية التربية النوعية جامعـة

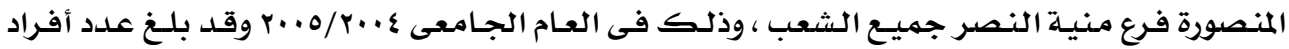

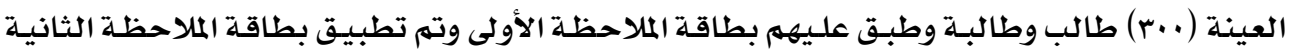

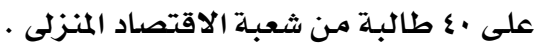
وقد اقتصر التطوير على الكفايات التدريسية المتعلقة بالتدريب الميدانى . • يتناول بداية التطوير (كفاية إدارة الصف) . • يقتصر التطبيق على طالبات الفرقة الرابعة شعبة الاقتصاد المنزلى .

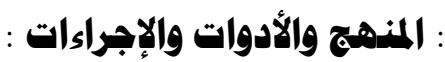

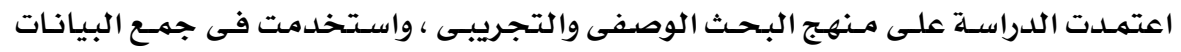

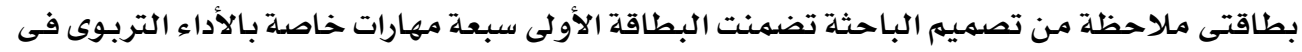

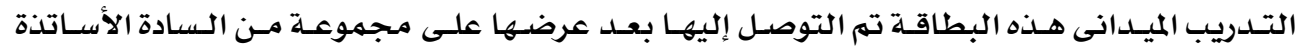

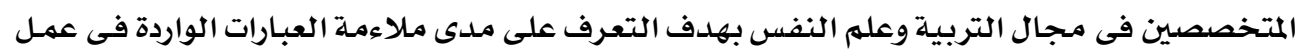

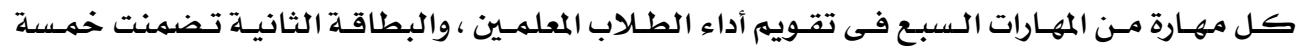

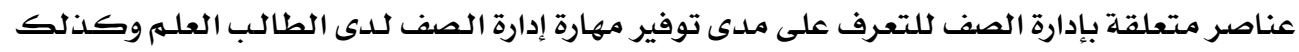

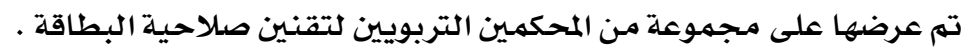

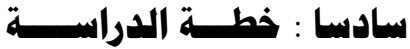

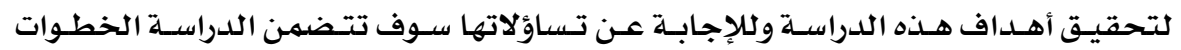

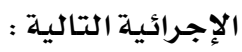

1- تقويهم الواقع الحالي للإعداد التربوى لطلاب كلية التربية النوعية وذلك عن طريق تحليل

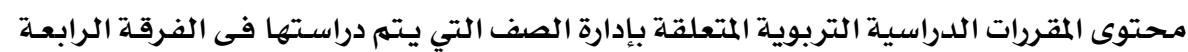

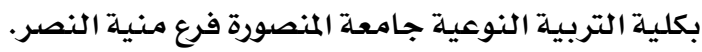

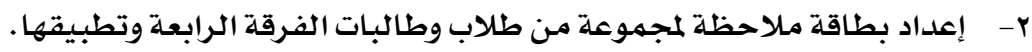

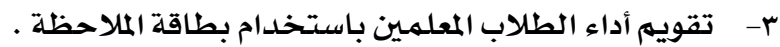

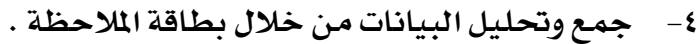

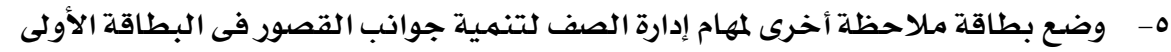

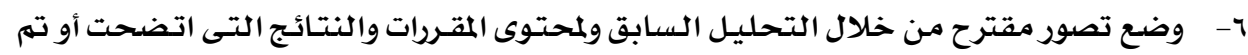

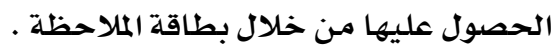

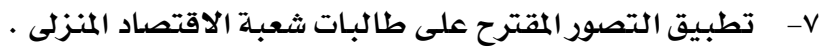

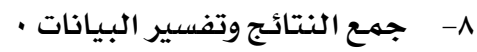




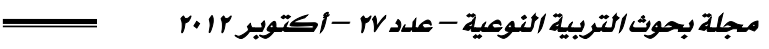

\section{نتائج البحث وتفسيرها}

تم تسجيل نتائج الدراسة الميدانية ومعالجتها إحصائيا وتفسير فروض البحث وكان ذلك الكان

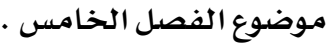

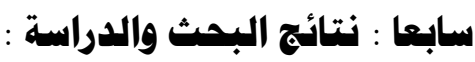

كشف البحث عن النتائج التالية :

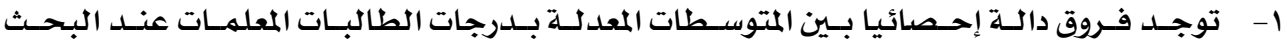

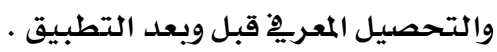

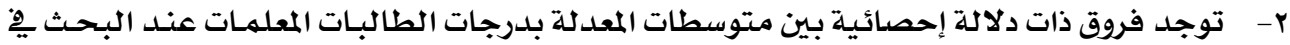

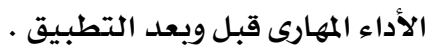

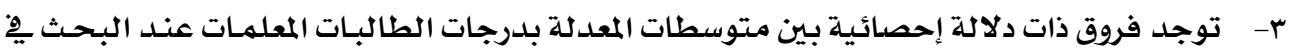
الأداء المهارى قبل وبعد التطبيق لكل كفاية على حلدة من الكاتل الكفايات الآتية :

$$
\begin{aligned}
& \text { • تنظيم البيئة الفيزيقية . } \\
& \text { • البيئة الاجتماعية البئة الفيزية } \\
& \text { • حفظ النظام . } \\
& \text { • تنظيم الخبرات } \\
& \text { • متابعة تقدم التلاميذ الخبرات . تنفيد }
\end{aligned}
$$


تصليل النتائج وتفسيرها أولاً : النتائج الخاصة بتشخيص واقع إعداد المعلم من خلال التدريب الميدانى (تتائج الدارسة التقويمية) جدول (1) المواصفات الشخصية والانفعالية والاجتماعية

\begin{tabular}{|c|c|c|c|}
\hline لصسالح فئلة & مستوى الدلالة & قيمـة " كاب " & العبارة \\
\hline مـرتفعة & دالة عند مستوى •, . & rr, & (1) \\
\hline متوسطة & دالة عند مستوى ه •, . & سr, & $(r)$ \\
\hline متوسطة & دالة عند مستوى ه ., . & $9 \cdot, \cdots$ & (r) \\
\hline مـرتفعة جداً & دالة عند مستوى ه ., . & Irq, TV & (飞) \\
\hline متوسطة & دالة عند مستوى ه •, . & IYT,TV & (0) \\
\hline ضعيفة & دالة عند مستوى 0 •., & $9 \cdot, \cdots$ & ( ( ) \\
\hline متوسطة & دالة عند مستوى ه •. . & $10 \cdot \ldots$ & $(\mathrm{v})$ \\
\hline مـرتفعـة & دالة عند مستوى ه •, . & $1 \leqslant 7,7 V$ & $(\wedge)$ \\
\hline مـرتفعـة جـاً & دانة عند مستوى •, . & rr,r & (9) \\
\hline ضعيفة & دالة عند مستوى ه ., . & $197,7 \mathrm{~V}$ & $(1 \cdot)$ \\
\hline مـرتفعة جداً & داثلة عند مستوى •, . & Ir/, & (11) \\
\hline مرتفعـة جدًا & دالة عند مستوى ه •, . & מח, & $(1 Y)$ \\
\hline متوسطة & دالة عند مستوى ه •, . & IVT,TV & $(1 r)$ \\
\hline مرتفعة & دالة عند مستوى •., . & $\wedge \bullet, \wedge \uparrow$ & (1乏) \\
\hline ضعيفة & دالة عند مستوى ه., . & $0 ., \cdots$ & $(10)$ \\
\hline متوسطة & دالة عند مستوى ه ., . & $17,7 V$ & $(17)$ \\
\hline متوسطة & داثلة عند مستوى •, . & $\mid r \cdot, \ldots$ & (IV) \\
\hline لا يوجد & دانة عند مستوى ه ., . & 117,78 & $(1 \wedge)$ \\
\hline مـرتفعـة & دالة عند مستوى 0 •. . & $11 \cdot, \ldots$ & $(19)$ \\
\hline متوسطة & دانة عند مستوى ه •, . & $M r \cdot, \ldots$ & $\left(r_{\cdot}\right)$ \\
\hline ضعيفة & دالة عند مستوى ه ., . & מr, מי & $\left(r_{1}\right)$ \\
\hline متوسطة & دالة مستوى ه •. . & Ir,.. & $(r y)$ \\
\hline مرتفعـة جدا & دالة عند مستوى ه., . & L & $(r r)$ \\
\hline
\end{tabular}

أوضسحت نتـائج الملاحظــة التـى قامست بها البـاحثـة بـشأن المواصـفات الشخـصية والانفعاليـة والاجتماعيـة أن مواصفات الطالب المعلم جاءت على نحو متوسط ، وهذا مـا أسـفرت عنـه المعايير المتفقق

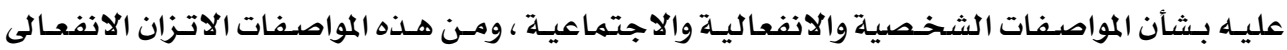
وقدرة الطالب المعلم على ضبط الذات حيث حصل على نسبـة مـرتفعـة جـلًا ( • ) طالبًا ، ومـرتفـع ( • ) طالبًا ، ومتتوسط ( •r| ) طالبًا وهى نسبـة تقترب من نسبـة ( .0 ٪) مـن إجمالى عدد الطلاب . 


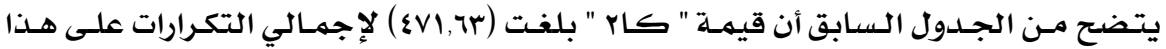

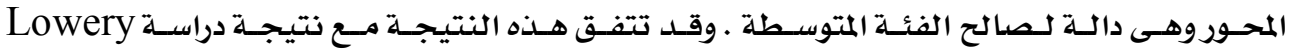
(1998) et al

وقد ترجع هـذه النتيجـة إلى درجـة اهتمـام الطالب المعلـم بالمواصفات الشخصية والانفعاليـة

والاجتماعية جاءت على نحو متوسط .

جدول (r) ) إدارة الصف

\begin{tabular}{|c|c|c|c|}
\hline لصسالح فئلة & مستوى الدلالدة & قيمـة " كاץ " & العبـارة \\
\hline متوسطة & دالة عند مستوى ه ., . & $0 ., \cdots$ & (1) \\
\hline متوسطة & دالة عند مستوى ه ., . & $07,7 \mathrm{~V}$ & $(r)$ \\
\hline ضعيفة & دالة عند مستوى ه •, . & rrr, & $(r)$ \\
\hline لا يوجد & دالة عند مستوى ه ., . & س & ( $\varepsilon)$ \\
\hline مـرتفعة & دالة عند مستوى ه •, . & IYV,O. & (0) \\
\hline ضعيفة & دالة عند مستوى ه ., . & $1 \cdot 7,7 \mathrm{~V}$ & $(7)$ \\
\hline متوسطة & دالة عند مستوى ه ., . & $11 \cdot \ldots$ & (v) \\
\hline ضعيفة & دالة عند مستوى ه ., . & $07,7 \mathrm{~V}$ & $(\wedge)$ \\
\hline متوسطة & دالة عند مستوى ه ., . & $\mid r \cdot, \cdots$ & (9) \\
\hline متوسطة & دالة عند مستوى ه •, . & س r,r, & $(1 \cdot)$ \\
\hline ضعيفة & دالة عند مستوى ه •, . & $110, \wedge r$ & $(11)$ \\
\hline مـرتفعة & دالة عند مستوى ه ., . & IrV,o. & $(I r)$ \\
\hline ضعيفة & دالة عند مستوى ه ., . & $7 \varepsilon, 1 V$ & (Ir) \\
\hline مـرتفعة & دالة عند مستوى ه ., . & $\boldsymbol{r}_{\cdot}, \ldots$ & $(1 \varepsilon)$ \\
\hline مـرتفعة جداً & دالة عند مستوى ه., . & $10 \cdot, \ldots$ & $(10)$ \\
\hline ضعيفة & دالة عند مستوى ه •, . & $1 \leqslant 7,7 V$ & $(17)$ \\
\hline ضعيفة & دالة عند مستوى ه ., . & TYY,VT & الإجمالى \\
\hline
\end{tabular}

أوضـحت نتائج الملاحظة التى قامـت بها الباحثة بشأن إدارة وحفظ النظـام داخل الفصل أن

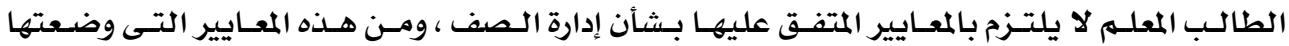

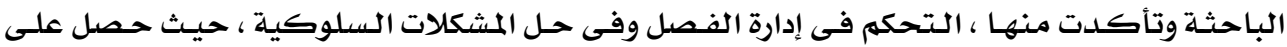

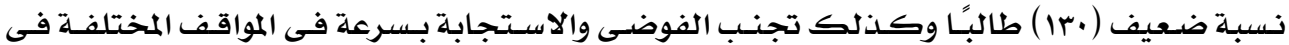

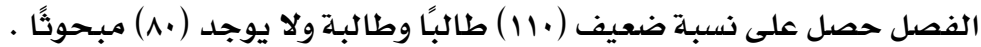

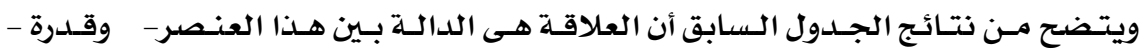

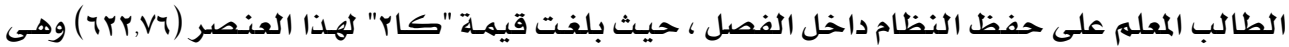

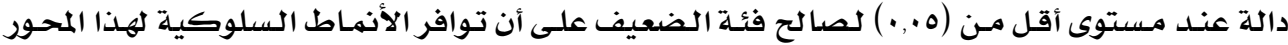
لدى الطلاب والمعلمـين جاءت على نحو ضعيف . لدئ 
وقد ترجع هذه النتيجة لقلة المهارات التدريسية لدى الطالب المعلم وحاجته الماسـة إلى وجـود

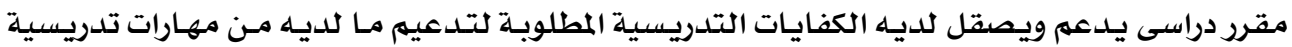
وصقل مهاراته التدريسية المطلوبة .

جدول (r) يوضح التخطيط والإعداد للدرس

\begin{tabular}{|c|c|c|c|}
\hline لصالح فئسة & مستوى الدلالة & قيمة " كاץ " & العبارة \\
\hline متوسط & دالة عند مستوى ه •, • & $117,7 \mathrm{~V}$ & (1) \\
\hline مـرتفع & دالة عند مستوى ه •, . & $107,7 \mathrm{~V}$ & $(r)$ \\
\hline متوسط & دالة عند مستوى ه •., & ror,ror & $(\mu)$ \\
\hline مرتفعة جداً & دالة عند مستوى ه •. • & rr,rir & $(\varepsilon)$ \\
\hline مرتفعة جـدًا & دالة عند مستوى ه •. & $117,7 V$ & (0) \\
\hline مرتفعة جداً & دالة عند مستوى ه •, . & $r r \cdot, \cdots$ & ( ( ) \\
\hline متوسط & دالة عند مستوى ه •, . & $11 \cdot, \cdots$ & (v) \\
\hline متوسط & دالة عند مستوى 0 .. . & r & $(\wedge)$ \\
\hline مرتفعة جدًا & دالة عند مستوى 0 ., . & r & (৭) \\
\hline مرتفعة جداً & دالة عند مستوى ه •., & YIT,TV & (1.) \\
\hline مرتفعة جدًا & دالة عند مستوى ه •, . & $19 \cdot, \cdots$ & (11) \\
\hline مرتفعة جــاً & دالة عند مستوى ه •. & $r 1 \cdot, \cdot$ & $(\mid r)$ \\
\hline متوسط & دالة عند مستوى 0 ., • & IVr,rr & (ir) \\
\hline ضعيفة & دالة عند مستوى 0 •., & $r_{1} \cdot, \cdots$ & ( $1 \xi)$ \\
\hline مرتفعة جداً & دالة عند مستوى ه ., . & אז,ri & $(10)$ \\
\hline مرتفعـة جداً & دالة عند مستوى $0 .$. & or.,... & الإجمالي \\
\hline
\end{tabular}

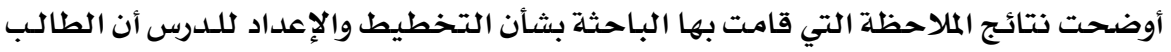

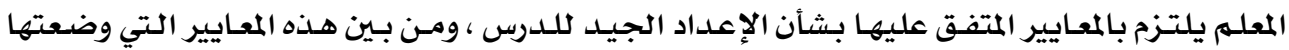

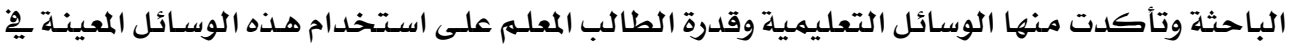

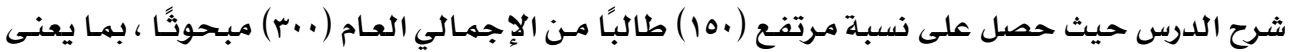

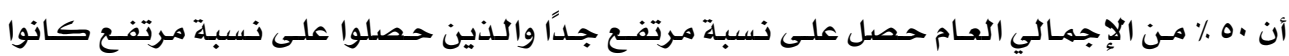

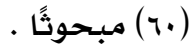

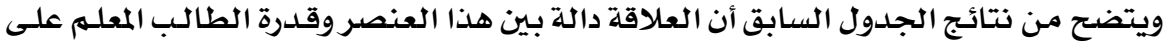

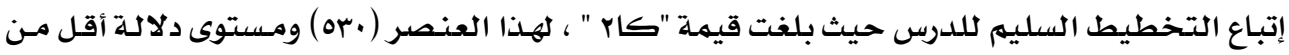

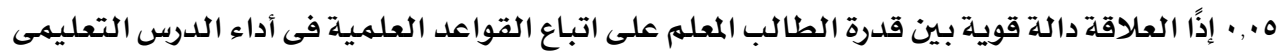

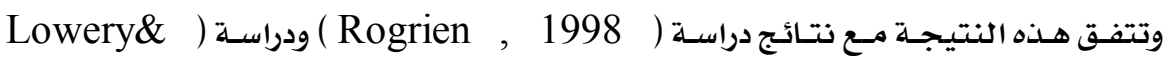

(Others, 1998 


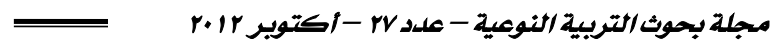

وقد ترجــ هـذه النتيـجـة إلى قـوة الإعـداد التربـوي والأكـاديهي التخصصصي ووعى الطالب

المعلم بطريقة إعداد الدرس والتخطيط له والتوعية من قبل المشرفين على التدريب الميداني .

جدول (ع) يوضتح مهارة تنفيذ الدرس

\begin{tabular}{|c|c|c|c|}
\hline لصساثح فئسة & مستوى الدلاكة & قيمة " كاץ " & العبـارة \\
\hline متوسطة & دالة عند مستوى 0 ., . & $1 \cdot 7,7 \mathrm{~V}$ & (1) \\
\hline مـرتفعة جـلًا & دالة عند مستوى ه •. • & Yo.... & $(r)$ \\
\hline مـرتفعـة & دالة عند مستوى ه •. . & $1 \cdot 7,7 \mathrm{~V}$ & (r) \\
\hline مـرتفعة جداً & دالة عند مستوى ه •. • & או,rדr & ( $\varepsilon)$ \\
\hline مـرتفعة & دالة عند مستوى ه .. & سז, & (0) \\
\hline مـرتفعة جـلًا & دالة عند مستوى •., & אוr,rד & (7) \\
\hline متوسطة & دالة عند مستوى ه ., . & $1 \cdot 7,7 \mathrm{~V}$ & $(\mathrm{v})$ \\
\hline متوسطة & دالة عند مستوى •., & سז,r\&l & $(\wedge)$ \\
\hline ضعيفة & دالة عند مستوى ه •. • & $11 \cdot, \cdots$ & (9) \\
\hline لا يوجد & دالة عند مستوى 0 .. . & $v \cdot, \cdots$ & $(1 \cdot)$ \\
\hline متوسطة & دالة عند مستوى ه... & IVT,TV & (11) \\
\hline ضعيفة & دالة عند مستوى ه ., . & rry, TV & $(I Y)$ \\
\hline متوسطة & دالة عند مستوى ه ., . & מr, & $(1 r)$ \\
\hline مـرتفعة & دالة عند مستوى 0 ., . & سז, & $(1 \varepsilon)$ \\
\hline لا يوجد & دالة عند مستوى ه •.. & $V \cdot, \cdots$ & (10) \\
\hline ضعيفة & دالة عند مستوى ه • , & $11 \cdot, \ldots$ & (17) \\
\hline مـرتفعة جداً & دالة عند مستوى ه... & אוז,rד & (IV) \\
\hline مـرتفعة & دالة عند مستوى ه ., . & س.r. & $(1 \wedge)$ \\
\hline متوسطة & دالة عند مستوى ه... & س & $(19)$ \\
\hline مـرتفعة & دالة عند مستوى 0 ., . & س.r.r & $\left(r_{\cdot}\right)$ \\
\hline مـرتفعة جدًا & دالة عند مستوى ه .. & IVT, TV & $\left(r_{1}\right)$ \\
\hline مـرتفحة & دالة عند مستوى 0 ., . & Y17, TV & $(r Y)$ \\
\hline مـرتفعة جداً & دالة عند مستوى ه •., & Y0T,TV & (rr) \\
\hline لا يوجد & دالة عند مستوى 0.,. & $19 \cdot, \ldots$ & $(r \varepsilon)$ \\
\hline متوسطة & دالة عند مستوى 0 .. • & $170,9 \mathrm{~V}$ & لإجمالي \\
\hline
\end{tabular}

أوضحت نتائج الملاحظة التى قامت بها الباحثة بشأن مهارة تنفيذ الدرس أن الطالب المعلمم

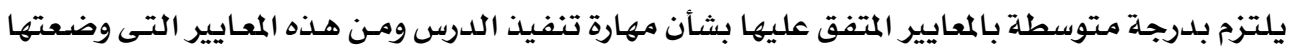
الباحثة وتأكدت منها عرض الدرس فى عناصـر مترابطة وتسلسل منطقى ، حيث حصل على نسبة 


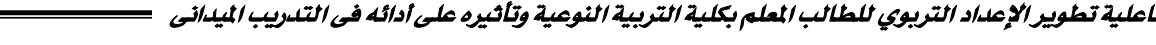

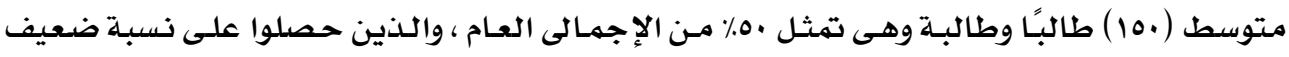
. (0.)

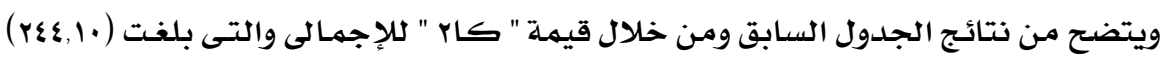

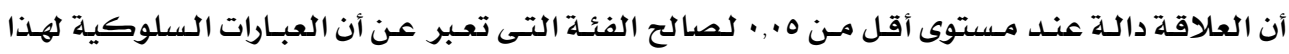

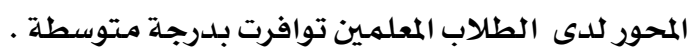

وتتفق هذه الدراسـة مـع نتيجة دراسـة ( Rogrien, 1998 ) وقد ترجـع هذه النتيـجـة إلى عدم

قدرة الطالب المعلهم على إدارة الصف وحفظ النظام مها انعكس على أدائه فى تنفيذ الدرس .

جدول (0) مهارة استخدام الوسائل التعليمية

\begin{tabular}{|c|c|c|c|}
\hline لصدالح فئكة & مستوى الدلاكة & قيمـة " كاץ " & العبارة \\
\hline مـرتفعة & دالة عند مستوى 0 •, . & rr,ry & (1) \\
\hline مرتفعة جدًا & دالة عند مستوى ه •, . & سז, & $(r)$ \\
\hline مـرتفعة جداً & دالة عند مستوى ه •, . & rr,rr & (r) \\
\hline متوسطة & 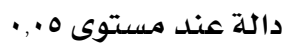 & מr,rrו & $(\varepsilon)$ \\
\hline مرتفعة & غير داثة & $17 \cdot, \cdots$ & (0) \\
\hline متوسطة & دالة عند مستوى •,. & $7,7 V$ & (7) \\
\hline مرتفعة & دالة عند مستوى 0 •, . & $11 \cdot, \ldots$ & (v) \\
\hline مرتفعة & دالة عند مستوى 0 •., & $\wedge \uparrow, 7 \vee$ & $(\wedge)$ \\
\hline متوسطة & دالة عند مستوى ه ., . & $1 \cdots, \cdots$ & (৭) \\
\hline & دالة عند مستوى 0 •. • & $11 \cdot, \cdots$ & $(1 \cdot)$ \\
\hline مـرتفعة & دالة عند مستوى 0 •, . & $7 \cdot, \cdots$ & $(11)$ \\
\hline متوسطة & غير دالة & $11 \cdot, \ldots$ & $(1 Y)$ \\
\hline متوسطة & دالة عند مستوى 0 •, . & $7,7 V$ & $(1 r)$ \\
\hline متوسط & دالة عند مستوى 0 .. . & $r \leqslant \varepsilon, 1$. & الإجمالى \\
\hline
\end{tabular}

أوضحت نتائج الملاحظة التى قامت بها الباحثة بشأن مهارة استخدام الوسـائل التعليهيـة أن

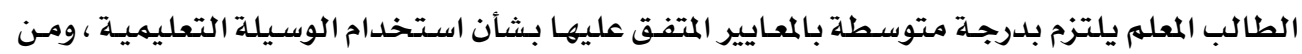

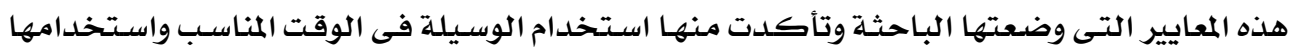

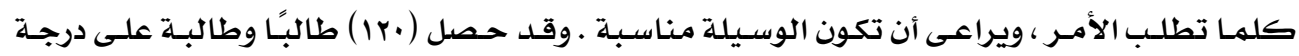

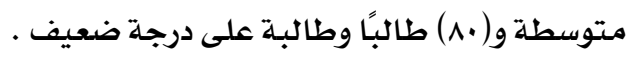
ويتضح من نتائج الجدول السـابق أن العلاقة دالة بين هذا العنصـر وقدرة الطابـ المعلـم على

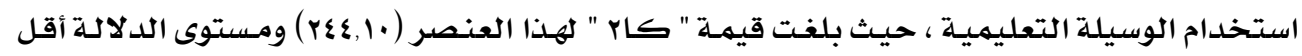

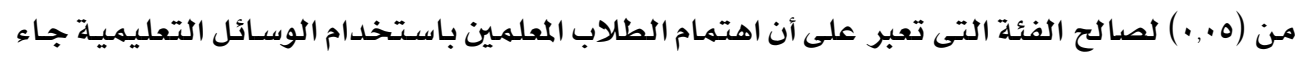
على نحو متوسط ، وقد ترجـع هذه النتيججة لعدم توافر الوسائل التعليميـة بالمدارس . 


\begin{tabular}{|c|c|c|c|}
\hline \multicolumn{4}{|c|}{ جدول (7) يوضتح مهارة التقويم } \\
\hline لصالح فئلة & مستوى الدلادة & قيمة " كاץ " & العبـارة \\
\hline ضعيفة & دالة عند مستوى 0 ., . & 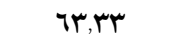 & (1) \\
\hline متوسطة & دالة عند مستوى ه ., . & $11 \cdot, \cdots$ & $(r)$ \\
\hline مـرتفعة & دالة عند مستوى ه •, & מצומצr & (r) \\
\hline ضعيفة & دالة عند مستوى 0 •, . & $q \cdot, \cdots$ & $(\varepsilon)$ \\
\hline متوسطة & دالة عند مستوى 0 •, . & או, & (0) \\
\hline & غير دالة & אוr,ra & $(7)$ \\
\hline ضعيفة & دالة عند مستوى ه •, . & $7,7 V$ & ( $\mathrm{v})$ \\
\hline مـرتفعة & دالة عند مستوى ه., . & rr,ru & $(\wedge)$ \\
\hline مـرتفعة جداً & دالة عند مستوى ه •, . & $1 V 7,7 V$ & (৭) \\
\hline متوسطة & دالة عند مستوى 0 ., . & $11 \cdot, \cdots$ & $(1 \cdot)$ \\
\hline لا يوجد & دالة عند مستوى ه •, . & $07,7 V$ & (11) \\
\hline ضعيفة & دالة عند مستوى $ه$., . & $1 \cdots, \cdots$ & $(1 Y)$ \\
\hline متوسطة & دالة عند مستوى ه •, . & מr, & $(1 \%)$ \\
\hline مـرتفعة & دالة عند مستوى ه •, . & מr, & $(1 \varepsilon)$ \\
\hline متوسطة & دالة عند مستوى ه •, . & سץ, س & $(10)$ \\
\hline ضعيفة & دالة عند مستوى 0 ., . & $9 \cdot, \cdots$ & $(17)$ \\
\hline متوسطة & دالة عند مستوى ه •, . & $7 \cdot, \cdots$ & (IV) \\
\hline مـرتفعة & دالة عند مستوى ه ., . & سr, & $(1 \wedge)$ \\
\hline مـرتفعة & دالة عند مستوى 0 ., . & سז, אוג & $(19)$ \\
\hline متوسطة & دالة عند مستوى 0 ., . & سז, M & $\left(r_{\cdot}\right)$ \\
\hline ضعيفة & دالة عند مستوى 0 ., . & Ir.,.. & $\left(r_{1}\right)$ \\
\hline ضعيفة & دالة عند مستوى ه ., . & $V 7,7 V$ & $(r y)$ \\
\hline ضعيفة & دالة عند مستوى ه ., . & $\varepsilon q \vee, \varepsilon Y$ & الإجهالى \\
\hline
\end{tabular}

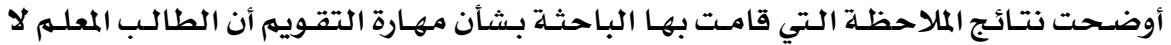

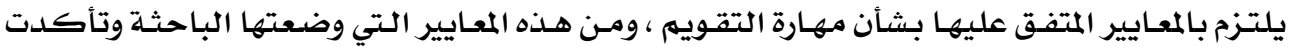

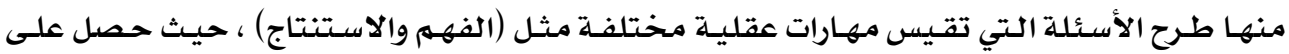

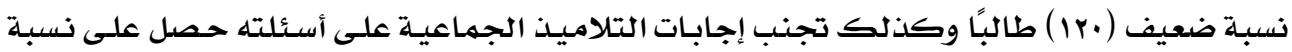

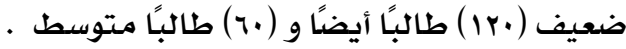

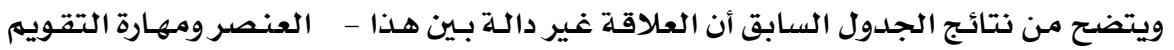

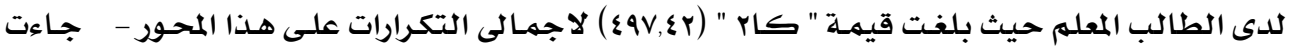


فاعلية تطوير الإعلداد التريوي للطالب المعلمر بكلية التربية النوعية وتاثيره على أدائه فى التلدريب الميدانى م

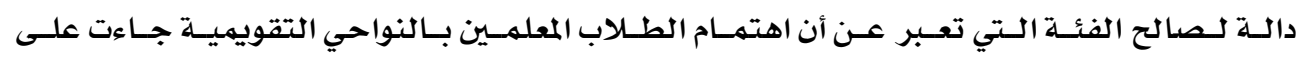
نحو ضعيف .

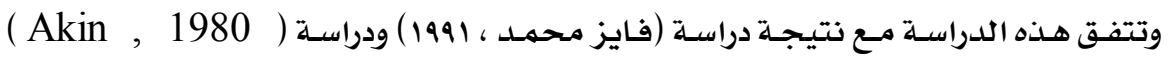

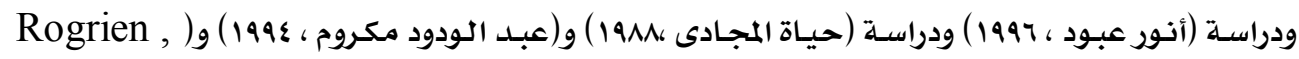

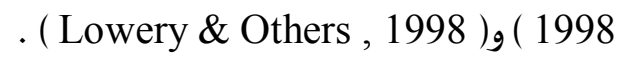

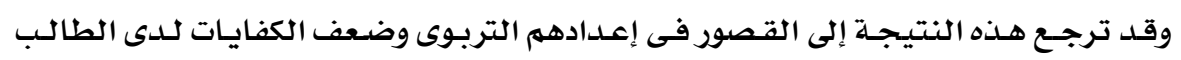

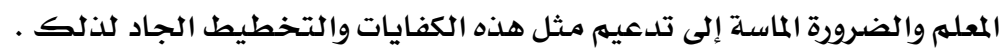

جدول (v) مهارة التعامل مـع التلاميذ

\begin{tabular}{|c|c|c|c|}
\hline لصـالح فئلة & مستوى الدلادة & قيمة " كاب " & العبـارة \\
\hline متوسطة & دالة عند مستوى 0 ., . & $11 \cdot, \cdots$ & (1) \\
\hline ضعيفة & دالة عند مستوى ه ., . & $V 7, T V$ & $(r)$ \\
\hline مـرتفعة & دالة عند مستوى ه ., . & rr,rr & $(r)$ \\
\hline ضعيفة & دالة عند مستوى $0 .$. & $9 \cdot, \cdot \cdots$ & $(\varepsilon)$ \\
\hline ضعيفة & دالة عند مستوى ه ., . & $V 7,7 V$ & (0) \\
\hline متوسطة & دالة عند مستوى ه ., . & $1 \cdots, \cdots$ & (7) \\
\hline متوسطة & دالة عند مستتوى ه., . & $11 \cdot, \ldots$ & $(v)$ \\
\hline ضعيفة & دالة عند مستوى ه •, . & VI, TV & $(\wedge)$ \\
\hline لا يوجد & دالة عند مستوى ه •. . & $117,7 V$ & (৭) \\
\hline متوسطة & دالة عند مستتوى ه., . & $1 \cdots, \ldots$ & (1.) \\
\hline ضعيفة & دالة عند مستتوى •.. & $\varepsilon V \varepsilon, r \mu$ & الإجمالى \\
\hline
\end{tabular}

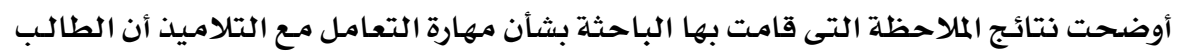

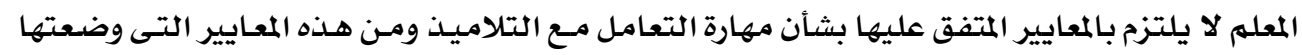

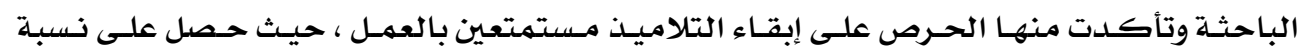

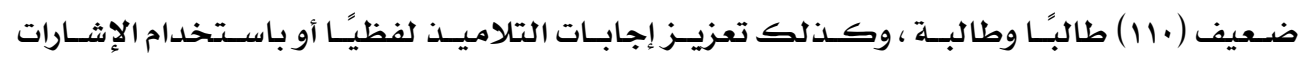

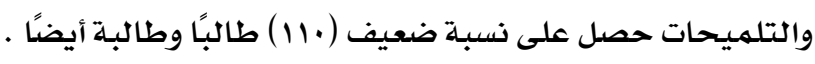

\section{لحساب نسبة تحقيق لأهداف}

قامت الباحثـة بحسـاب نسبة تحقيق الأهـداف لكل مـادة مـن المواد موضوع التحليـل وكانت

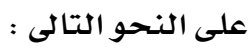




\begin{tabular}{|c|c|}
\hline \multicolumn{2}{|r|}{ جـدول (^) مهارة التعامل مـع التـلاميذ } \\
\hline نسبة تحقيق الأهداف & المـــــادة \\
\hline$\% \wedge \varepsilon, \operatorname{ar}$ & مادة المناهج للفرقة الرابعة ل \\
\hline$\% 9 \cdot, 91$ & مادة (طرق التدريس الفرقة الرابعة جميع الشعب) \\
\hline$\%$ 97, or & مادة مبادئ تدريس ثلّه الفرقة الثانية جميع الشعب للّه \\
\hline$\% \wedge \wedge, \vee$ & علم النفس التربوى للّه الفرقة الرابعة للّه \\
\hline$\%$ ro, $\mathrm{rI}$ & مادة محاضرات فى الإدارة التعليمية والتربوية للّ الفرقة الرابعة جميع الشعب \\
\hline
\end{tabular}

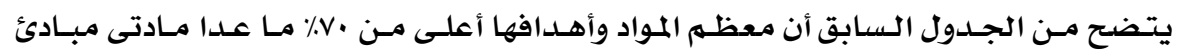

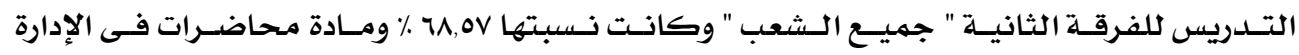

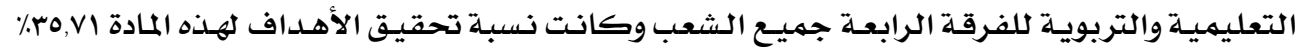

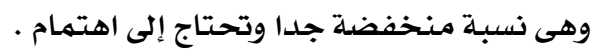

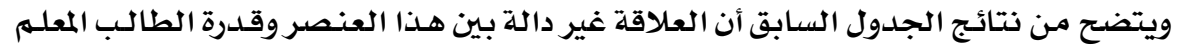

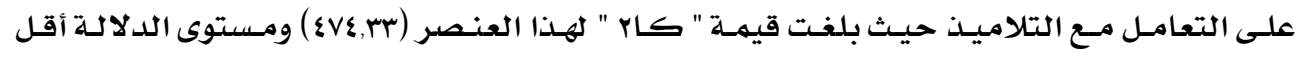

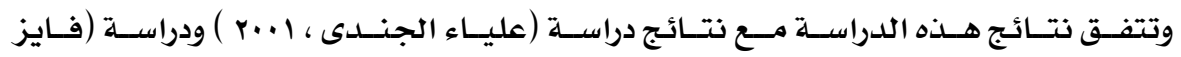

ثانيا : ثتائج الدراسة التجريبية

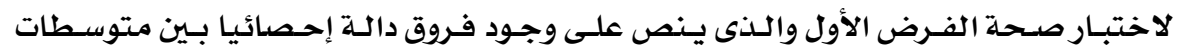

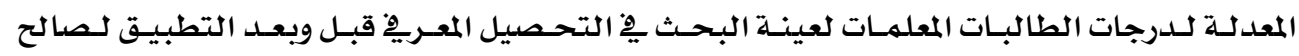

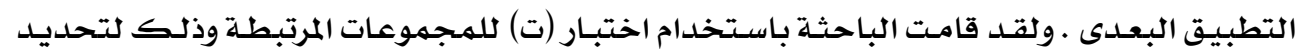

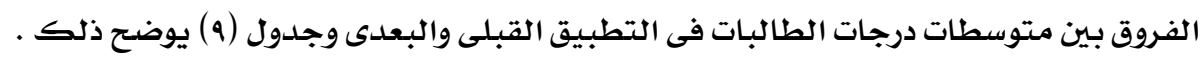

(a) جدول)

\begin{tabular}{|c|c|c|c|c|c|c|}
\hline الدلالة الإحصائية & قيمة ت & درجة الحرية & الانحراف المعياري & المتوسط & التطبيق & الكفاية \\
\hline دالة & $v, r$ & 9 & $\begin{array}{l}\text { 1, Troq } \\
\text { 1, rrAY }\end{array}$ & $\begin{array}{l}\text { 1, ro } \\
\text { r,Ero }\end{array}$ & قبلى & تنظيي البيئة \\
\hline دالة & $v$, sIV & rq & $\begin{array}{l}1,\{\wedge 10 \\
1,1 \vee 7 \xi\end{array}$ & $\begin{array}{c}1,8 \\
r,\{\times 0\end{array}$ & قبلى & توفير المناخ \\
\hline دالة & r,riv & rq & $\begin{array}{l}\text { 1, ros } \\
\text { 1, rาs }\end{array}$ & $\begin{array}{l}\text { 1,Yo } \\
1, \text { Avo }\end{array}$ & قبلى & حفظ النظام \\
\hline دالة & $\boldsymbol{\varepsilon}, \wedge \vee \wedge$ & rq & $\begin{array}{l}1,\{7 V \varepsilon \\
1,\{V \leqslant \varepsilon\end{array}$ & $\begin{array}{l}\text { svo. } \\
\text { r,. Yo }\end{array}$ & قبلى & تلظظيم الخبرات \\
\hline دالة & $\{, 700$ & ra & $\begin{array}{l}\text { 1, Trar } \\
1, \text { olor }\end{array}$ & $\begin{array}{l}1,7 \\
r, 1\end{array}$ & قبلى & متابعة الطلاب \\
\hline دالة & $1 \cdot, 0 . r$ & rq & $\begin{array}{l}Y, Y Y Y I \\
\xi, A \mid \xi Y\end{array}$ & $\begin{array}{l}v, \text { vo } \\
1,90\end{array}$ & قبلى & النتيجة الكلية \\
\hline
\end{tabular}




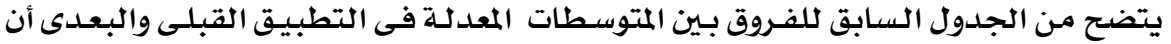

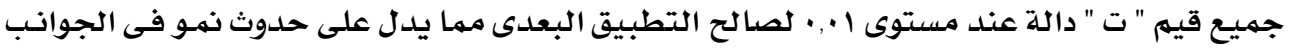

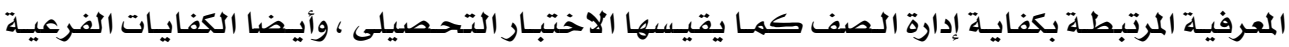

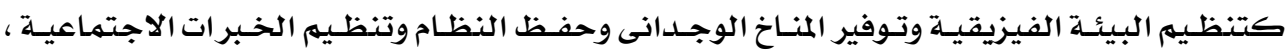

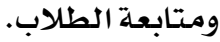

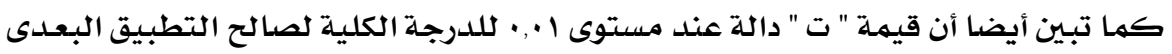

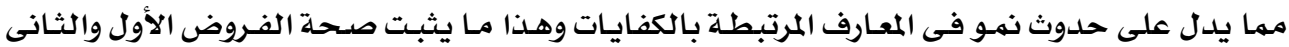

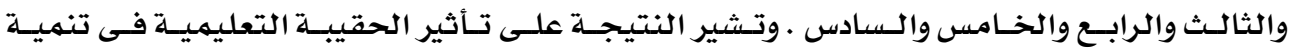
التحصيل لدى عينة البحث .

\section{تحلديد فعالية الحقيبة التعليمية في تنمية التحصيل:}

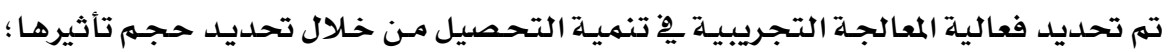

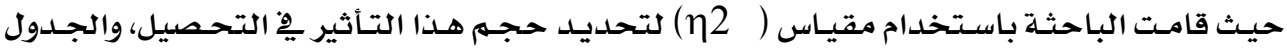

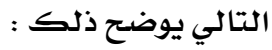

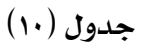

قيم ( ) وحجم تأثير المعالجة التجريبية هٍِ التحصيل

\begin{tabular}{|c|c|c|}
\hline حجم التأثير & قيمـة & البيان \\
\hline كبير & $\cdot, 911$ & الدرجة الكلية يِّ التحصيل \\
\hline
\end{tabular}

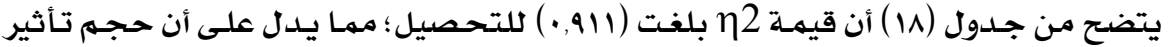
المعالجة التجريبية كبير ِِّ تنمية التحصيل لدى عينة البحث.

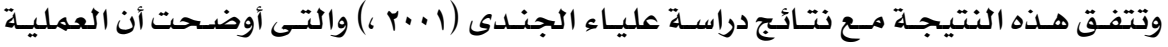

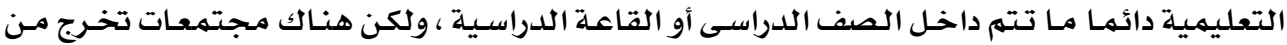

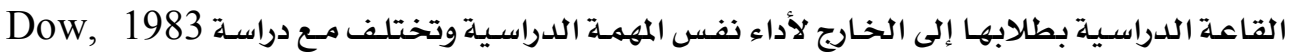
Hurber. et al., ودراسة (1990) ثانيا : تتائج تطبيق البطاقة الخاصة بكفاية إدارة الصف : لاختبار صحة الفرض السـابع والذى ينص على :

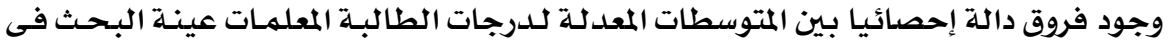

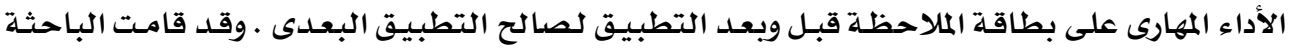

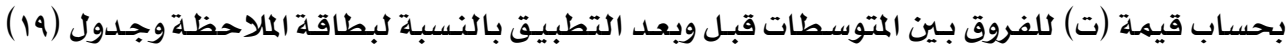
يوضح ذلك . بكابك 
جدول (II)

قيمة " ت " ودلالتها الإحصائية للفرق بين متوسطي درجات عينة البحث

2ِ التطبيقين القبلى والبعدى فِ مهارات بطاقة الملاحسظة والدرجة الكلية

\begin{tabular}{|c|c|c|c|c|c|c|c|}
\hline مستوى الدلاية & قيمة " ت " & درجات الحرية & الانحراف المايعياري & المتوسط & $\dot{j}$ & القياس & المهارة \\
\hline \multirow{2}{*}{ دالة عند ا•,. } & \multirow{2}{*}{19,171} & \multirow{2}{*}{$r q$} & Y,Erry & ri, qro & $\varepsilon \cdot$ & البعلي & \multirow{2}{*}{ الأولي } \\
\hline & & & $\varepsilon$, rsto & II, Aro & $\xi$. & القبلي & \\
\hline \multirow{2}{*}{ دالة عند ا+,. } & \multirow{2}{*}{$19,00 Y$} & \multirow{2}{*}{ ra } & $\varepsilon, 1 \leqslant 9 A$ & $r q, q$ & $\xi$. & البعلي & \multirow{2}{*}{ الثانية } \\
\hline & & & $8, \cdot 9 \cdot 7$ & rr, rro & $\varepsilon$. & القبلي & \\
\hline \multirow{2}{*}{ دالة عند ا•, • } & \multirow{2}{*}{$r r, O \cdot V$} & \multirow{2}{*}{ rq } & $\varepsilon, \cdot \cdot 1 r$ & $09, r$ & $\xi$. & البعلي & \multirow{2}{*}{ الثالثة } \\
\hline & & & $9, r \leqslant 77$ & $r r, \cdot r o$ & $\varepsilon \cdot$ & القبلي & \\
\hline \multirow{2}{*}{ دالة عند اי,. } & \multirow{2}{*}{19,790} & \multirow{2}{*}{ rq } & 1,977r & rr, IVo & $\varepsilon \cdot$ & البعدي & \multirow{2}{*}{ الرابعة } \\
\hline & & & $\varepsilon,\{\rceil \cdot \varepsilon$ & 11,90 & $\varepsilon \cdot$ & القبلي & \\
\hline \multirow{2}{*}{ دالة عند ا+, • } & \multirow{2}{*}{ Y^,^Ar } & \multirow{2}{*}{ rq } & $\varepsilon, \wedge r \eta \wedge$ & \&l, $\vee$ & $\varepsilon \cdot$ & البعلي & \multirow{2}{*}{ الخامسة } \\
\hline & & & O, YAYI & $19, r$ & $\varepsilon$. & القبلي & \\
\hline \multirow{2}{*}{ دالة عند ا•, • } & \multirow{2}{*}{ ro,rry } & \multirow{2}{*}{ rq } & $11,19 v 8$ & 1100,00 & $\xi$. & البعلي & \multirow{2}{*}{ الكلية } \\
\hline & & & $r v, \cdots r r$ & 91, rro & $\varepsilon$. & القبلي & \\
\hline
\end{tabular}

يتضح من جدول (19) أن هناك فروقا دالة إحصائيًا بـين درجـات التطبيقين القبلي والبعـدي

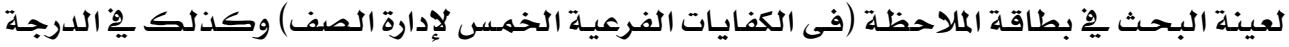

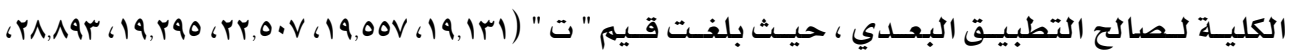

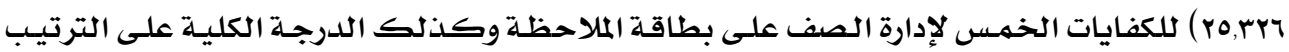

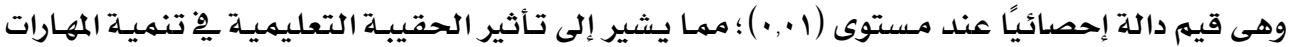

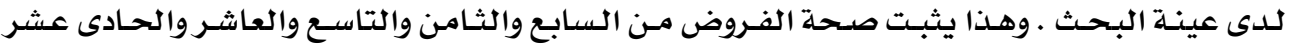

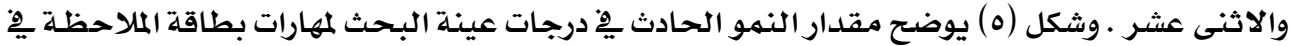

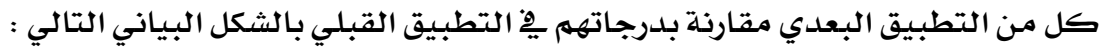

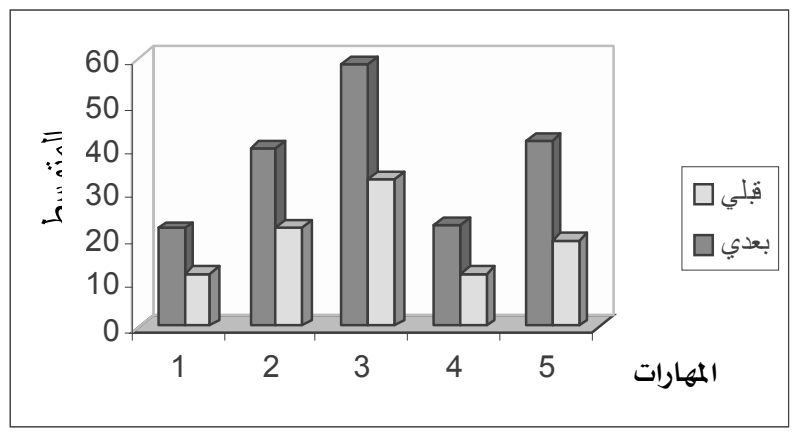

شكل (1)

متوسطات درجات عينة البحث يِّ التطبيق القبلي والتطبيق البعدي لمهارات بطاقة الملاحظة والدرجة الكلية 


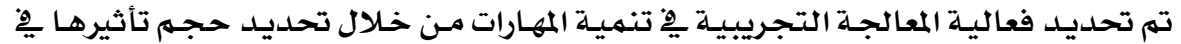

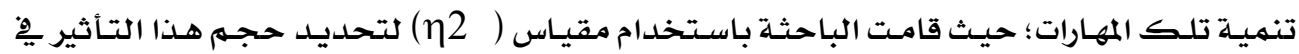

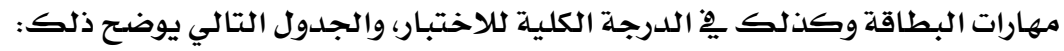

جدول (ir)

قيم ( 12) وحجم تأثير المعالجة التجريبية على مهارات بطاقة الملاحظة والدرجة الكلية (1ا)

\begin{tabular}{|c|c|c|}
\hline حجم التأثير & قيهة & المهارات \\
\hline كبير & $\cdot, 9 \cdot 4$ & الأولى \\
\hline كبير & $\cdot, 9 \cdot 4$ & الثانية \\
\hline كبير & $\cdot, 9 Y \wedge$ & الثالثة \\
\hline كبير & $\cdot, 9.0$ & الرابعة \\
\hline كبير & $\cdot, 900$ & الخامسة \\
\hline كبير & 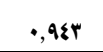 & اللدرجة الكلية \\
\hline
\end{tabular}

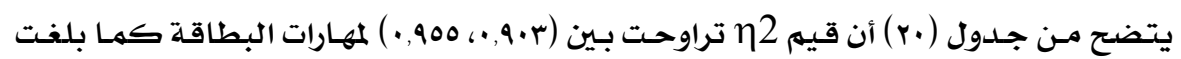

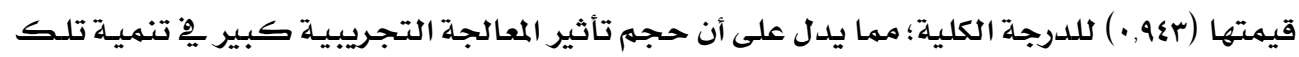
المهارات لدى عينة البـحث.

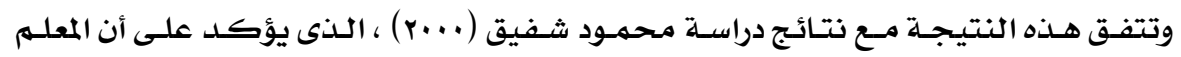

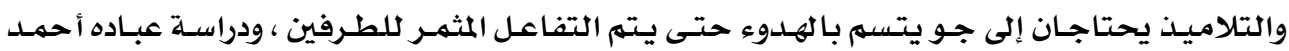

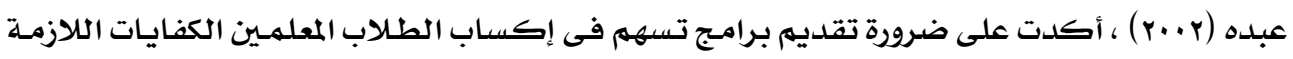

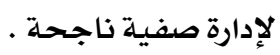

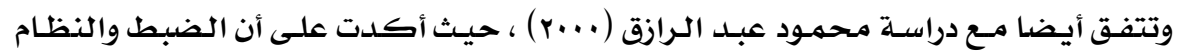

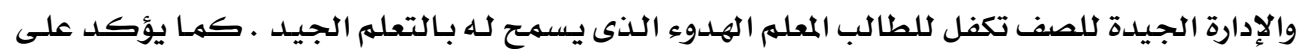

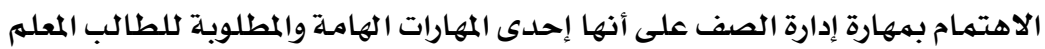

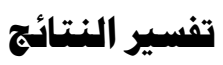

أولا : النتائج التقويمية

وقد أثـارت نتائج تحليل المحتوى للمقررات الدراسية شعبة الاقتصـاد المنزلى إلى وجـود قصور

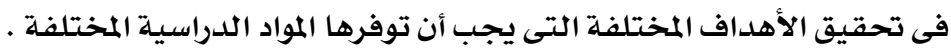

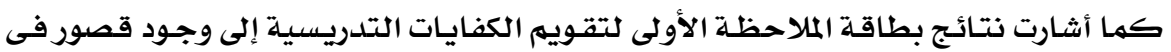
أداء الطالبات فى التدريب الميدانى . 
تشير نتائج تطبيق الاختبـار التحصيلى إلى وجـود فروق ذات دلالدة احصائيا بـين متوسطات التسات

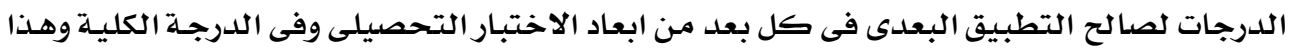

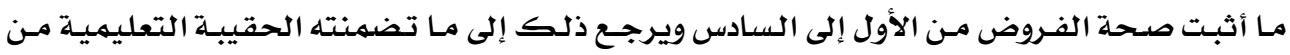

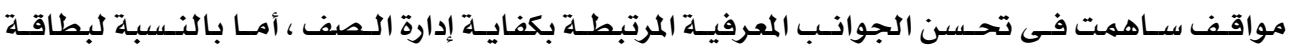

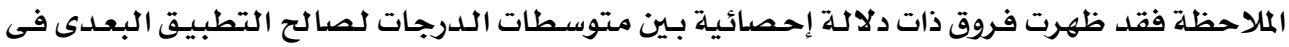

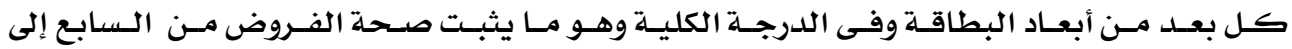
الثامن عشر . ويتضح مما سبق أن تطوير الإعداد التربوى قد يتمثل فى تطوير الجوانب الأدائيـة المختلفـة

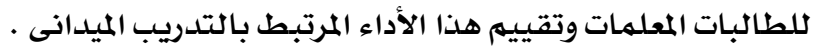

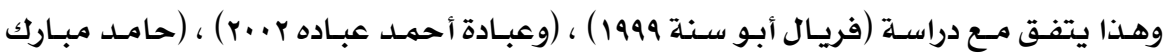

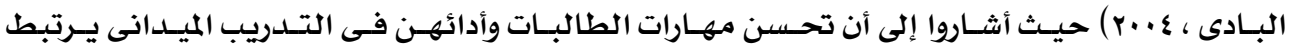

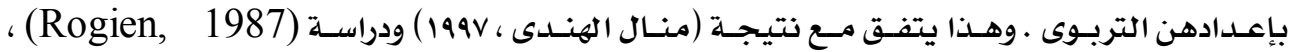

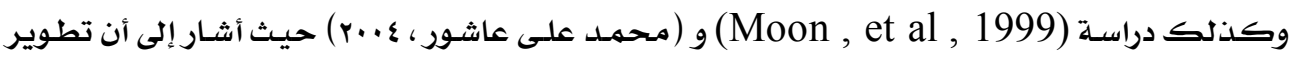

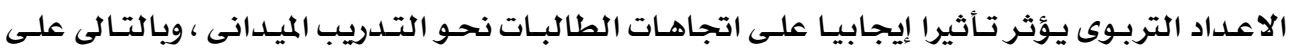

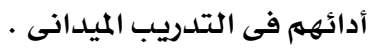

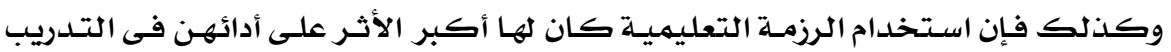

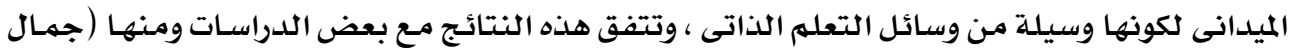

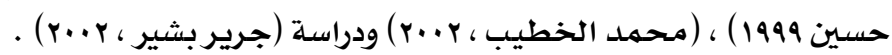

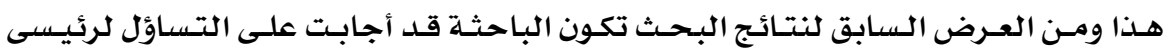

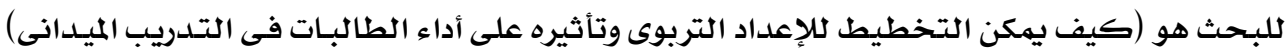

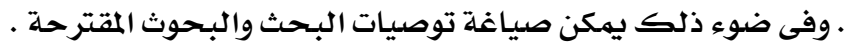

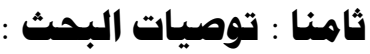

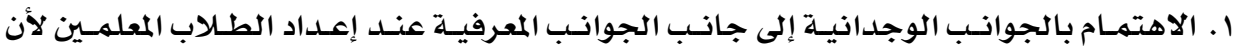

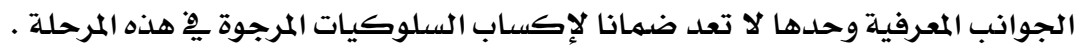

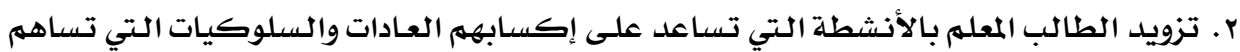

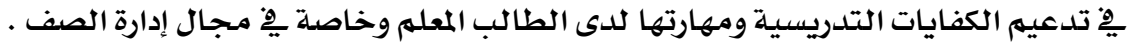

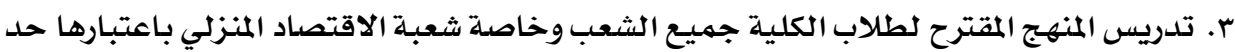

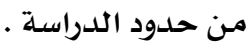

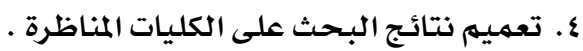

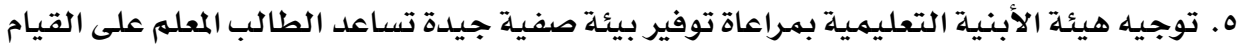

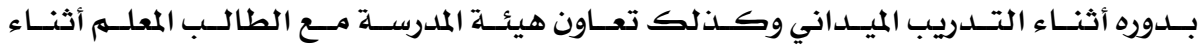
فترة التدريب. 


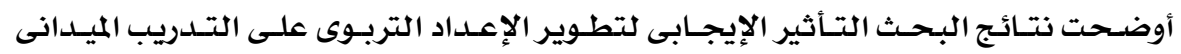

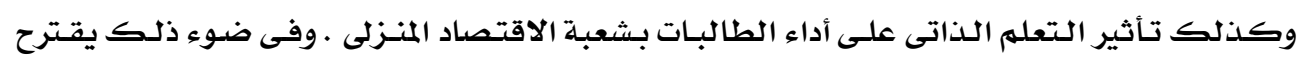

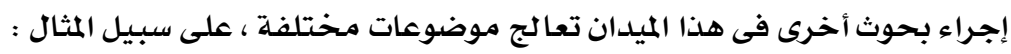
1- دراسـة تهدف إلى استخدام التعلهم الذاتى وتأثيرها على أداء الطالبات وأثره على الأداء .

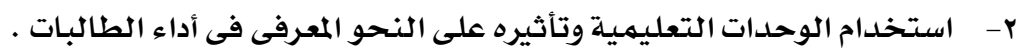

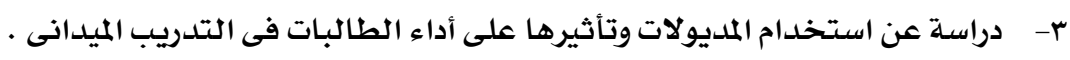

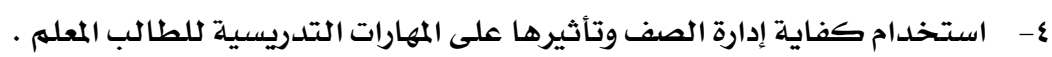




\section{المراجــع}

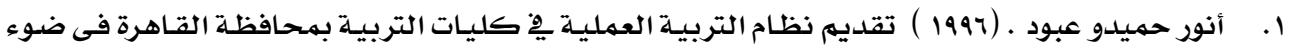

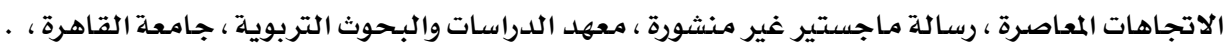

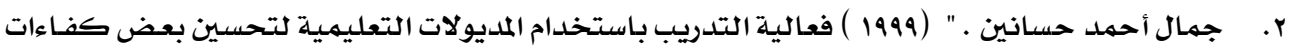

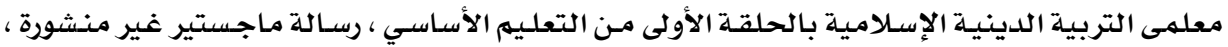

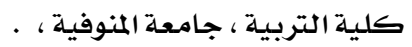

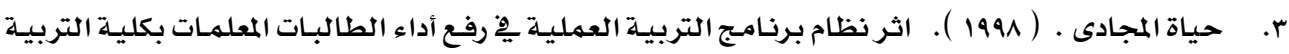

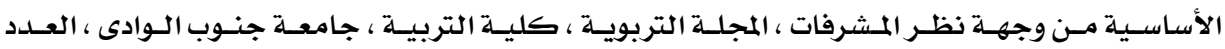
(r)

عباده أحمد عباده الخولى ـ مدى فاعلية برنامج لتدريب الطلاب المعلمين وإنتاج بـرامجج تعليميـة تفاعليـة ،

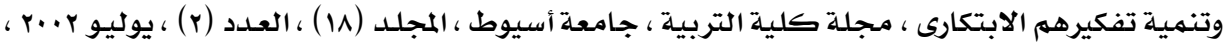

$$
\text { ص ص } 9.9 \text {. } 9 \text {. }
$$

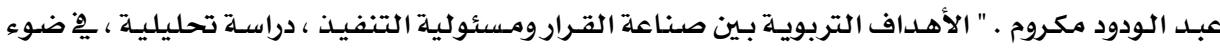

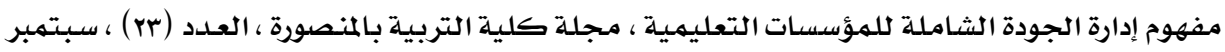
1997 ،ص ص س. זr. .

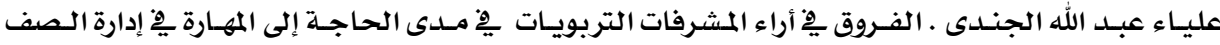

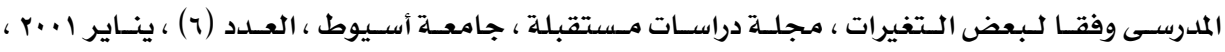
ص ص ص

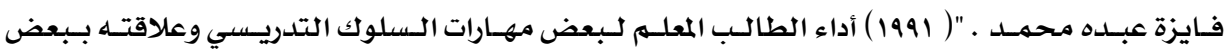

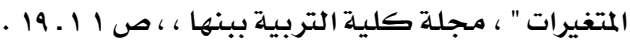

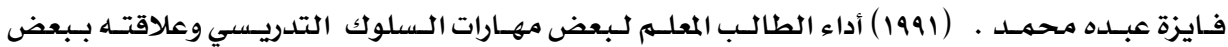
المتغيرات ، مجلة كلية التربية ببنها ، ، ، ص ص . ـ 19 .

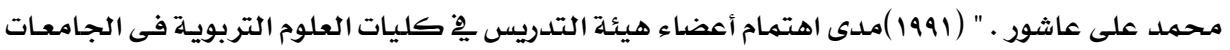
الحكوميـة بالبـحوث المرتبطة بالتطور التربـوى ، مجلـة العلـوم التربويـة والنفسية ، كليـة التربيـة ، جامعـة

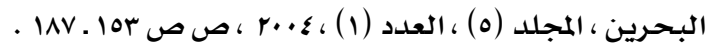

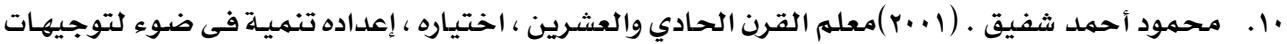

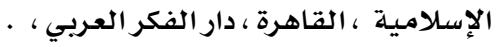

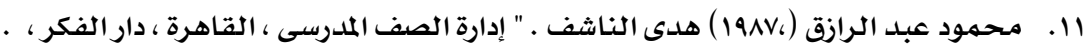

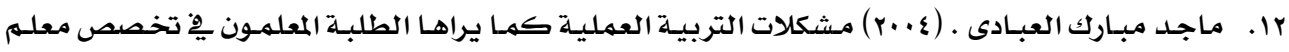

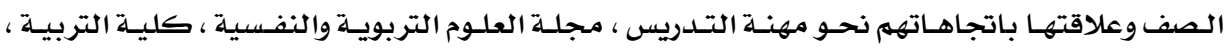

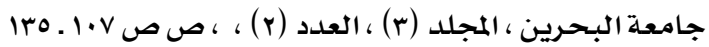


فاعلية تطوير الإعلاد التريوي للطالب المعلم بكلية التربية النوعية وتاثيره على أدائه فى التلدريب الميدانى س

13. Dow, L.M., 1984 " Principals " Evaluation of teaching prefovmence of recent G.raduates of Elementary and secondary undergraduate teacher Eduction programns at the university of southern Mississippi . Dis . Ans. Int, Vol. (45), No (3-A), Sept. , P. 737.

14. Haber . 2712. Patricia Ann; A Modifiec training program for presrvice teacher to optimize pupil Moror Engaagement time " Dis, Abs . Int. Vol. (51), No. ( 8 - A), 1995, P.

15. Lowery 1998. et al., Construction of teacher Knowledge in contect ; preparing Elementary teachers to teach Mathematics and science, Dis . Abs Inst, Vol., (59) No. (4-A) , , P. 112.

16. Moon, T. R et al . 1999 " The Effects of Mentoring relationships . on prosevvise teachers, Attituds toward academically Diverse students " Gifted child Quartevly, Vol. (43), No. (2), , P. 56 - 62 ..

17. Rogien \& Lawrece \& Robert 1533, " The Effects of cognitive strategy training in clarity of Instruction on lesson planning and Instruction proservice teacher students teacher's Dis. Abs Int. Vol. (59), No. (5-A), 1998, P. 